\title{
Review of A Marvelous Experience, edited by Lili Liao-AME Publishing Company, Hong Kong, 2018
}

\author{
Ramón Rami-Porta ${ }^{1,2}$ \\ ${ }^{1}$ Department of Thoracic Surgery, Hospital Universitari Mútua Terrassa, University of Barcelona, Terrassa, Barcelona, Spain; ${ }^{2}$ Network of Centers \\ for Biomedical Research in Respiratory Diseases (CIBERES) Lung Cancer Group, Terrassa, Barcelona, Spain \\ Correspondence to: Ramón Rami-Porta, MD, PhD, FETCS. Department of Thoracic Surgery, Hospital Universitari Mútua Terrassa, University of \\ Barcelona, Plaza Dr. Robert 5, 08221 Terrassa, Barcelona, Spain. Email: rramip@yahoo.es.
}

Submitted Feb 23, 2020. Accepted for publication Mar 14, 2020.

doi: $10.21037 /$ jtd.2020.03.09

View this article at: http://dx.doi.org/10.21037/jtd.2020.03.09

During the 2019 European Conference on General Thoracic Surgery, organized by the European Society of Thoracic Surgeons in Dublin, Republic of Ireland, I visited the AME stand in the exhibition area. Once there, I was presented with A Marvelous Experience, edited by Lili Liao. I thanked the AME staff for their kindness, I put the book in my backpack and, I must confess, I forgot about it, busy as I was trying to cope with the conference programme. By the time I was ready to leave Dublin to come back to Spain, I realized that, due to my immoderate reading, I had not properly rationed the book I had taken with me, with the result that I had consumed it all. The book in question was De Profundis, by Wilde, written 121 years before the publication of $A$ Marvelous Experience, when Ireland was not an independent nation and its inhabitants were not Irish nationals, but British. With no time to get another decent book to read on my way back, when I was in the taxi that took me to the airport, I remembered the book in my backpack. I put my hand in it and there it was. I was relieved: I had something to read. I started reading it as I was waiting to board my plane and I continued reading it during the entire flight. I simply could not put it down. I must say that I did not expect much of it, but I was hooked to it from the first pages of this extraordinary story. I finished it that same evening at home and it left me with a profound feeling of satisfaction and gratitude to the authors and the editor of the book that I could not have anticipated.

A Marvelous Experience, of slightly over 100 pages, is divided into four chapters and prefaced by Dr. Stephen D. Wang, founder and CEO of AME Publishing Company, and by Dr. Alan D. L. Sihoe, a well-known thoracic surgeon from Hong Kong, whose presence is always expected in our European congresses. The first chapter describes how the Annals of Cardiothoracic Surgery (ACS) was created, as an example of how to establish a new journal. The creation and development of ACS is a success story that parallels the success story of all the publications of the AME Publishing Company. Central to the success of $A C S$ was the appointment of its Editor-in-Chief, Dr. Tristan Yan, a professional with brilliant medical background, a hardworking man, a person with vision, and not alien to the suffering associated with the role of Editor-in-Chief. As one of the sections of this chapter is entitled, 'Suffering drives a person to achieve even more', so wrote Wilde from his prison: 'to have become a deeper man is the privilege of those who have suffered' (1). Intelligent people draw the best from suffering and difficulties, and Dr. Yan did so when he dared to take the responsibility to lead $A C S$ to an indexed, respectable journal in a record time of 6 years.

If one thought that one had seen everything related to books, chapter two of A Marvelous Experience will show how mistaken one was. Nowadays we still have (fortunately) books in the traditional format; we have printed books that have online support that can be accessed with a password one needs to find by scratching a surface behind the cover; we have books in digital format to read on computer and tablet screens; and we have the 'mooks', a hybrid between a magazine and a book. AME published its first mook in 2015 and at the time of publication of $A$ Marvelous Experience there already were more than 50 . But what is a mook? Well, if you look it up in an urban dictionary of the English 
language, you will be disappointed, as it comes to be a fourlettered slang derogative term that has nothing to do with publishing. In the new context of the AME Publishing Company, a mook is a collection of related articles already published on a specific topic, bound together to provide the reader with the updated information provided by a journal, but also with the depth of a traditional book. Because the content of the mook has not to be written anew, its production is much easier and faster than that of a book. And even more: mooks can be customized. The reader can choose the articles to be compiled and bound, so that the mook is personalized to the reader's will. That's brilliant, isn't it?

Chapters three and four deal with editorial activities that go far beyond traditional publishing, with the objective, first, to increase the visibility of Chinese medical science led by thousands of Chinese doctors and researchers; and, second, to facilitate the connectivity not only among Chinese and international doctors, but also among doctors and patients. AME has been present in many international medical meetings and this has allowed the international community to know their achievements. AME also has interviewed many Chinese and international doctors, so that they can explain what their motivations are, what they work in, and how they manage to achieve their objectives. I was interviewed, too, (2) and that interview, together with other 33, was collected in an elegantly bound bookanother innovative publishing initiative-that contains a lot of insight into the present trends on lung cancer management around the world (3). This series of interviews, published in the AME journals, has been extremely useful to understand the work done in China and internationally. Until very recently, Chinese doctors and their activities were practically unknown. Circumstantial constraints for travelling in and out of China and the language barrier kept us all together in a state of mutual ignorance. But this is history. Now, the presence of our Chinese colleagues in international forums has increased enormously and their presentations are expected with thrilling anticipation. This improved interaction has facilitated mutual understanding and professional collaboration. There is no doubt that China, with its great number of patients, has become a popular destination for short-term training programs for foreign doctors. A foreign thoracic surgeon, for example, spending a few weeks in a high-volume Chinese hospital will see many more surgical procedures than in any other institution. Foreign doctors, on the other hand, can bring their expertise in planning scientific activities, designing databases or suggesting publications, putting their background to the service of our Chinese colleagues with the ultimate objective to serve our patients wherever they are (4).

Patients' opinions, fears, worries and expectations count now more than ever before. Patient reported outcomes are valued and included now in many databases. What they think, feel and expect is important to us. Chapter four of A Marvelous Experience explains how AME managed to connect doctors and patients by creating a network of international experts that can be summoned for multidisciplinary consultations. This is done through a platform called iMDT Corner, associated to the first AME journal, Fournal of Thoracic Disease. The iMDT allows patients to receive medical advice from international doctors without the need to leave their home. The platform not only links doctors and patients, but also doctors among themselves. The connection is multilateral, facilitating the exchange of opinion and the mutual understanding of attitudes and practices.

Reading A Marvelous Experience is a delight. Its prose is fluent and fresh; the type setting is easy to read; and the general layout is pleasant to the eye. It can be read as a capturing biography, as this is what it is: the biography of a new model of medical publishing that has made a real revolution in the publishing world and has altered the relationship between Chinese doctors and doctors around the world. Persistence is a word that is often mentioned in the book. Interestingly enough, this is the word I wrote in capital letters in the text I was asked to write for AME before the publishing of $A$ Marvelous Experience (5). I am happy to share the idea with CEO Dr. Stephen D. Wang that persistence is the key to success.

Ten years of successful activity is not an anecdote. The amount of grey matter behind AME Publishing Company pushing its way through a rather rigid and ankylosed publishing system has reduced the barriers between author and publisher, has maintained the quality of reputed peerreviewed journals, and has increased the possibilities of disseminating medical research in many areas of medical knowledge. AME's more than 60 journals, one-third of them indexed in PubMed, attests for the quality of the work done in this past decade. A Marvelous Experience explains all this.

Wilde wrote: 'With freedom, books, flowers and the moon, who could not be happy?' (1). He considered the book an element of happiness and I can only concur with him. A Marvelous Experience made me very happy, and I 
have all reasons to think that it will make future readers very happy, too.

\section{Acknowledgments}

Funding: None.

\section{Footnote}

Provenance and Peer Review: This article was commissioned by the Editorial Office, Fournal of Thoracic Disease. The article did not undergo external peer review.

Conflicts of Interest: The author has no conflicts of interest to declare.

Ethical Statement: The author is accountable for all aspects of the work in ensuring that questions related to the accuracy or integrity of any part of the work are appropriately investigated and resolved.

Open Access Statement: This is an Open Access article distributed in accordance with the Creative Commons
Attribution-NonCommercial-NoDerivs 4.0 International License (CC BY-NC-ND 4.0), which permits the noncommercial replication and distribution of the article with the strict proviso that no changes or edits are made and the original work is properly cited (including links to both the formal publication through the relevant DOI and the license). See: https://creativecommons.org/licenses/by-nc-nd/4.0/.

\section{References}

1. Wilde O. De Profundis, The Ballad of Reading Gaol and Other Writings. London: Wordsworth Editions, 1999:86.

2. Li GS, Shen J. The lung cancer research career of Prof. Ramón Rami-Porta: passion, vision and reflection. J Thorac Dis 2017;9:E1025-31.

3. Sihoe ADL, Li GS, Zhang VKP. editors. Meet the Professor. The Experts' Perspective on Management of Lung Cancer. Hong Kong: AME Publishing Company, 2017.

4. Sihoe AD. Opportunities and challenges for thoracic surgery collaborations in China: a commentary. J Thorac Dis 2016;8:S414-26.

5. Liao L. editor. A Marvelous Experience. 1st ed. Hong Kong: AME Publishing Company, 2018:66.
Cite this article as: Rami-Porta $\mathrm{R}$. Review of $A$ Marvelous Experience, edited by Lili Liao-AME Publishing Company, Hong Kong, 2018. J Thorac Dis 2020;12(3):156-158. doi: $10.21037 /$ jtd.2020.03.09 